\title{
Control of Bitterweed with Herbicides
}

\author{
D.N. UECKERT, C.J. SCIFRES, S.G. WHISENANT, AND J.L. MUTZ
}

\begin{abstract}
Herbicide 2,4-D was less effective for bitterweed control when applied at air temperatures below $14^{\circ} \mathrm{C}$ compared to applications at $22^{\circ} \mathrm{C}$ even when soil water was adequate for active plant growth. There was no difference in bitterweed control whether the ester or amine formulations of 2,4-D were used. At $22^{\circ} \mathrm{C}$ air temperature, $1.12 \mathrm{~kg} / \mathrm{ha}$ of $2,4-\mathrm{D}+$ dicamba (3:1), picloram, or 2,4,5-T + picloram (1:1) did not improve short-term control (36 to 182 days) of bitterweed compared to 2,4-D alone at the same rate. However, at $14^{\circ} \mathrm{C}$ temperature or when bitterweed were in advanced phenological states ( $75 \%$ with inflorescences), these herbicides provided excellent short-term bitterweed control whereas 2,4-D was inconsistent. Mixtures of dicamba with 2,4-D slightly improved residual bitterweed control, compared to the same rate of 2,4-D alone. Picloram at 0.56 to $1.12 \mathrm{~kg} / \mathrm{ha}$ controlled 60 to $100 \%$ of the bitterweed populations for a year or more following applications in winter or spring. Tebuthiuron at 0.56 to $1.12 \mathrm{~kg} / \mathrm{ha}$ was not as effective as 2,4-D at $1.12 \mathrm{~kg} / \mathrm{ha}$ relative to initial bitterweed control, but provided excellent residual control after 1 year following winter application.
\end{abstract}

Bitterweed (Hymenoxys odorata DC.) occurs throughout most of the southern Great Plains and Southwest (Clawson 1931), and is recognized as a major poisonous plant on the Edwards Plateau of Texas (Sperry 1949). Death losses of sheep attributed to bitterweed poisoning on the Edwards Plateau average 1 to 6\% annually (Sultemeier 1961). Bitterweed is a major factor, along with predators and unavailability of labor, causing the $50 \%$ decline in sheep numbers over the past 30 years in West Texas.

Boughton and Hardy (1937) reported that the acute $\mathrm{LD}_{50}$ of fresh seedling bitterweed in sheep averaged $1.3 \%$ of body weight, but may be as low as $0.5 \%$ of body weight during prolonged drought. Dollahite et al. (1973) reported acute $\mathrm{LD}_{50}$ values for air-dried bitterweed of 3.6 to $8.5 \mathrm{~g} / \mathrm{kg}(0.36$ to $0.85 \%$ of body weight). Hymenoxon, a sesquiterpene lactone, has been isolated as a toxic principle in bitterweed (Kim et al. 1975).

Sperry (1949) stressed the importance of good grazing management for avoiding bitterweed poisoning. However,

\footnotetext{
Authors are associate professor, professor, research associate, and assistant research scientist, Texas Agricultural Experiment Station at San Angelo, College Station, San Angelo, and Corpus Christi, respectively.

This report is approved by the Director, Texas Agricultural Experiment Station as TA-14837.

The authors wish to express their appreciation to J.R. Scifres for typing and manuscript preparation. Also, the authors wish to acknowledge George Sultemeier and Robert E. Steger, Texas Agricultural Extension Service, and numerous County Agricultural Extension agents for assistance in installation and evaluation of these experiments. Land for this research was provided by Reginald Atkinson, Bill Scott and Hal Noelke, Mertzon; Bill Pfluger, San Angelo; Tony Allen, Ozona; S.K. Horwood, Sterling City; and Jimmy Powell, Ft. McKavett, Texas.

Manuscript received February 8, 1979.
}

reduced cover of forage plants following periodic droughts and short-term overgrazing results in continual bitterweed poisoning on the Edwards Plateau. Also, many ranchers hesitate to utilize mechanical brush control practices since soil disturbance encourages bitterweed infestations.

Broadcast application of 2,4-D ([2,4-dichlorophenoxy] acetic acid) ester is effective for short-term control when soil water is favorable for bitterweed growth (Sperry and Sultemeier 1965). Bunting and Wright (1974) reported excellent control of bitterweed with an unidentified 2,4-D amine applied between November 1 and January 15, apparently regardless of plant phenology or environmental conditions. However, bitterweed control with 2,4-D has severe limitations, including: (1) limited control of seedlings emerging after treatment; and (2) unsatisfactory control of bitterweed when growing conditions are unfavorable or when bitterweed is in advanced phenological stages.

Environmental conditions, as they regulate plant growth and physiology, strongly influence weed control with foliarapplied, translocated herbicides such as $2,4-\mathrm{D}$. Sperry and Sultemeier (1965) reported that 20 to $25 \%$ soil-water contents were critical for controlling $90 \%$ or more of the bitterweeds with 2,4-D on clay soils. However, the influence of air or soil temperatures on herbicidal control of bitterweed has not been reported.

Rate of absorption of foliar-applied herbicides, within biological limits, tends to double with each $10^{\circ} \mathrm{C}$ increase in temperature (Klingman and Ashton 1975; Leopold and Kriedemann 1975). For example, foliar uptake of 2,4-D at $25.5^{\circ} \mathrm{C}$ was two to three-fold that at $10^{\circ} \mathrm{C}$ during a $12-\mathrm{hr}$ period (Ashton and Crafts 1973). Rate and extent of translocation of 2,4-D also increases with increased temperature, so less herbicide may be required at moderate temperature (i.e. 20 to $25^{\circ} \mathrm{C}$ ) than at lower temperatures (i.e. $10^{\circ} \mathrm{C}$ ) for absorption and translocation of lethal amounts of herbicide.

This research was initiated to identify herbicides which extend effective bitterweed control compared to 2,4-D, and which are effective over a wider range of weather and phenology of bitterweed.

\section{Materials and Methods}

Beginning in 1975, various herbicides and herbicide combinations (Table 1) were applied aerially or with ground equipment in winter or spring at seven locations on the Edwards Plateau in West-Central Texas. Herbicides were applied in 140 liters/ha of a diesel oil:water (1:14) emulsion containing $0.1 \%(\mathrm{v} / \mathrm{v})$ emulsifier or 
Table 1. Herbicidal treatments evaluated for bitterweed control on the Edwards Plateau.

\begin{tabular}{|c|c|c|c|}
\hline Common name(s) & Chemical name(s) & Formulation(s) & $\begin{array}{c}\text { Rates } \\
\text { (kg/ha, a.i.) }\end{array}$ \\
\hline 2,4-D & (2,4-dichlorophenoxy)acetic acid & $\begin{array}{l}\text { dimethylamine salt (DMA) } \\
\text { 2-ethylhexyl ester } \\
\text { dimethylamine salt }+ \text { 2-ethylhexyl } \\
\text { ester }(1: 1) \\
\text { alkanolamine salt }\end{array}$ & $\begin{array}{l}0.84,0.94,1.12 \\
0.84,1.12 \\
1.12 \\
1.12\end{array}$ \\
\hline $\begin{array}{l}\text { 2,4-D + dicamba } \\
\quad(3: 1)\end{array}$ & $\begin{array}{l}\text { (2,4-dichlorophenoxy)acetic acid }+ \\
\text { 3,6-dichloro-o-anisic acid }\end{array}$ & dimethylamine salts & $0.56,1.12$ \\
\hline $\begin{array}{l}2,4,5-T+\text { picloram } \\
(1: 1)\end{array}$ & $\begin{array}{l}\text { (2,4,5-trichlorophenoxy)acetic acid } \\
+4 \text {-amino-3,5,6-trichloropicolinic } \\
\text { acid }\end{array}$ & $\begin{array}{l}\text { triethylamine salt } \\
\text { diethylamine salt }\end{array}$ & $0.56,1.12$ \\
\hline Picloram & 4-amino-3,5,6-trichloropicolinic acid & potassium salt & $0.14,0.28,0.56,1.12$ \\
\hline Tebuthiuron & $\begin{array}{l}\mathrm{N}-(5-[1,1-\text { dimethylethyl]-1,3,4- } \\
\text { thiadiazol-2-yl)- } N,,^{\prime} \text {-dimethylurea }\end{array}$ & $80 \%$ wettable powder & $0.56,1.12$ \\
\hline
\end{tabular}

in 218 liters/ha of water containing $0.1 \%(\mathrm{v} / \mathrm{v})$ surfactant with a small-plot tractor sprayer equipped with a 6-m boom. Treatments were applied to 6 by $30-\mathrm{m}$ or 18 by $30-\mathrm{m}$ plots and were replicated three times in completely random or randomized complete block designs. Herbicides were aerially applied in $12-\mathrm{m}$ wide swaths with fixed-wing aircraft in 9.3 liters/ha of a diesel oil:water (1:4) emulsion. Aerially treated plots were 6.2 to 11.3 ha, depending on location, and were not replicated.

Herbicides were aerially applied in the oil:water emulsion near Mertzon on December 16, 1975. On that date and on May 6, 1976, experiments were also installed near Mertzon with ground equipment, using water and surfactant as a carrier.

Three experiments were installed with ground equipment in 1976: near San Angelo on December 7; near Ozona on December 10; and near Barnhart on December 15. In these experiments, herbicides were applied in the diesel oil:water emulsion carrier except tebuthiuron which was applied in water only. In addition, the diesel oil:water emulsion carrier without herbicide was applied to one set of plots to allow isolation of any potential carrier effects. On December 8, 1976, herbicides were aerially applied in water containing commercial surfactant to single plots near Barnhart. Herbicides were applied in diesel oil:water emulsion carriers with ground equipment on April 20, 1977, near Sterling City and on April 22, 1977, near Ft. McKavett.

Live bitterweed plants were counted $36,140,182$, and 310 days after treatment in twenty-five $0.25-\mathrm{m}^{2}$ quadrats, equidistantly spaced on a diagonal across each aerially treated plot and in five quadrats similarly located on ground-treated plots near Mertzon. Percentage reduction in density of live bitterweed plants, based on densities of the appropriate untreated plot, were subjected to the inverse sine transformation before analyses of variance were conducted.

In all other experiments with ground equipment, live bitterweeds were counted in ten permanent $0.1 \mathrm{~m}^{2}$ quadrats equidistantly spaced along a diagonal across each plot. Sampling dates were 48,113 , and 489 days after December 1976 treatments, and 40 and 354 days after April 1977 treatments. Although transformed data were considered, final analyses of covariance were conducted on actual densities of surviving bitterweeds using pretreatment densities as a covariate. Data are presented as mean percentage reduction in adjusted live bitterweed densities.

Thirty permanent $0.2-\mathrm{m}^{2}$ quadrats were established on plots aerially treated near Barnhart. Percentage reduction in live bitterweeds after 48 and 113 days was based on pretreatment densities.

From three to 15 soil samples were collected from each experimental area at 0 to 3,3 to 8,8 to 15 , and 15 to $30 \mathrm{~cm}$ deep at time of herbicide application. Soil water content was determined gravimetrically. Duplicate subsamples were characterized relative to $\mathrm{pH}$ on a 1:1 slurry, organic-matter content by acid digestion and titration, and textural components by the hydrometer method. Rainfall data were obtained from the nearest U.S. Weather Bureau recording station. Air temperature was recorded at $2 \mathrm{~m}$ and soil temperature was recorded at $2.5 \mathrm{~cm}$ depth at initiation and termination of herbicide application in each experiment.

\section{Results and Discussion}

\section{Control with 2,4-D}

Soils of the Mertzon sites were sandy clay loams (Table 2) and were typified by rocky outcrops. Although fall precipitation was below average for the study area near Mertzon, rainfall for the 60-day period prior to spraying was above normal. Environmental conditions the day of spraying were highly favorable for herbicide absorption and translocation.

Table 2. Selected soil characteristics from locations where herbicides were evaluated for bitterweed control on the Edwards Plateau.

\begin{tabular}{|c|c|c|c|c|c|c|}
\hline \multirow{2}{*}{$\begin{array}{l}\text { Depth } \\
(\mathrm{cm})\end{array}$} & \multirow[b]{2}{*}{$\mathrm{pH}$} & \multirow{2}{*}{$\begin{array}{c}\text { O.M. } \\
(\%)\end{array}$} & \multicolumn{3}{|c|}{ Textural components $(\%)$} & \multirow{2}{*}{$\begin{array}{c}\text { Textural } \\
\text { class }^{1}\end{array}$} \\
\hline & & & sand & silt & clay & \\
\hline \multicolumn{7}{|c|}{ Barnhart } \\
\hline $0-8$ & 7.7 & 3.0 & 18 & 50 & 32 & Scl \\
\hline $8-15$ & 7.8 & 2.3 & 13 & 47 & 40 & Scl \\
\hline $15-30$ & 7.8 & 2.3 & 17 & 47 & 36 & Scl \\
\hline \multicolumn{7}{|c|}{ Ft. McKavett } \\
\hline $0-8$ & 7.3 & 6.1 & 18 & 57 & 25 & Scl \\
\hline $8-15$ & 7.4 & 5.1 & 15 & 50 & 35 & Scl \\
\hline $15-30$ & 7.5 & 4.6 & 12 & 47 & 41 & Scl \\
\hline \multicolumn{7}{|c|}{ Mertzon } \\
\hline $0-8$ & 7.4 & 3.7 & 1 & 48 & 50 & Scl \\
\hline $8-15$ & 7.6 & 2.2 & 1 & 45 & 54 & Scl \\
\hline $15-30$ & 7.6 & 2.0 & $<1$ & 44 & $>56$ & Scl \\
\hline \multicolumn{7}{|c|}{ Ozona } \\
\hline $0-8$ & 7.5 & 4.2 & 15 & 57 & 28 & Scl \\
\hline $8-15$ & 7.6 & 3.0 & 12 & 44 & 32 & Scl \\
\hline $15-30$ & 7.7 & 2.5 & 11 & 44 & 24 & Scl \\
\hline \multicolumn{7}{|c|}{ San Angelo } \\
\hline $0-8$ & 7.6 & 5.8 & 18 & 62 & 20 & Sl \\
\hline $8-15$ & 7.6 & 5.9 & 19 & 57 & 24 & Sl \\
\hline $15-30$ & -2 & - & - & - & - & - \\
\hline \multicolumn{7}{|c|}{ Sterling City } \\
\hline $0-8$ & 7.6 & 2.7 & 31 & 52 & 17 & Sl \\
\hline $8-15$ & 7.7 & 2.6 & 24 & 57 & 19 & Sl \\
\hline $15-30$ & 7.7 & 2.7 & 23 & 52 & 25 & Sl \\
\hline
\end{tabular}

'Scl-Sandy clay loam; $\mathrm{Sl}=$ Sandy loam; $\mathrm{Sc}=$ Sandy clay.

${ }^{2}$ Rock content of samples from 15 to $30 \mathrm{~cm}$ deep prevented accurate analysis. 
Table 3. Percentage reduction in live bitterweed densities at $36,140,182$, and 310 days after ground broadcast application of various herbicides and herbicide combinations on December 16, 1975, near Mertzon, Texas

\begin{tabular}{lccccc}
\hline \hline & \multirow{2}{*}{$\begin{array}{l}\text { Rate } \\
\text { Herbicide(s) }\end{array}$} & \multicolumn{4}{c}{ Days after treatment } \\
\cline { 3 - 6 } & & 36 & 140 & 182 & 310 \\
\hline None & - & $0 \mathrm{a}$ & $0 \mathrm{a}$ & $0 \mathrm{a}$ & $\mathrm{a}$ \\
2,4-D amine & 0.56 & $23 \mathrm{bc}$ & $91 \mathrm{~b}$ & $61 \mathrm{~b}$ & $0 \mathrm{a}$ \\
2,4-D amine & 1.12 & $35 \mathrm{~cd}$ & $91 \mathrm{~b}$ & $81 \mathrm{~cd}$ & $19 \mathrm{bc}$ \\
2,4-D ester & 0.56 & $10 \mathrm{ab}$ & $97 \mathrm{~b}$ & $75 \mathrm{bc}$ & $0 \mathrm{a}$ \\
2,4-D ester & 1.12 & $52 \mathrm{e}$ & $99 \mathrm{~b}$ & $93 \mathrm{de}$ & $42 \mathrm{~d}$ \\
2,4-D + dicamba (3:1) & 0.56 & $0 \mathrm{a}$ & $100 \mathrm{~b}$ & $68 \mathrm{bc}$ & $0 \mathrm{a}$ \\
2,4-D + dicamba (3:1) & 1.12 & $5 \mathrm{a}$ & $100 \mathrm{~b}$ & $98 \mathrm{e}$ & $30 \mathrm{~cd}$ \\
Picloram & 0.14 & $0 \mathrm{a}$ & $100 \mathrm{~b}$ & $80 \mathrm{~cd}$ & $14 \mathrm{ab}$ \\
Picloram & 0.28 & $38 \mathrm{cde}$ & $100 \mathrm{~b}$ & $97 \mathrm{e}$ & $25 \mathrm{bcd}$ \\
Picloram & 0.56 & $50 \mathrm{de}$ & $100 \mathrm{~b}$ & $95 \mathrm{de}$ & $72 \mathrm{e}$ \\
\hline
\end{tabular}

'Means within a column followed by the same letter are not significantly different at $P<0.05$ according to Duncan's new multiple range test.

Air temperatures reached $22^{\circ} \mathrm{C}$ by termination of herbicide applications at 2 P.M. At the time of spray initiation at midmorning, surface soil temperature was $9^{\circ} \mathrm{C}$, and reached $16^{\circ} \mathrm{C}$ by termination of herbicide application. Soilwater content averaged $20 \%$ in the upper $8 \mathrm{~cm}$ and $27 \%$ in the 8 to $75 \mathrm{~cm}$ depth.

No precipitation occurred on the Mertzon study areas from the time of spraying to the first evaluation of bitterweed response, 36 days later. Surviving bitterweed plants were wilted and there was little difference in bitterweed control with the DMA or ester formulations of 2,4-D within an application rate (Table 3). Bitterweed control from aerial applications of 2,4-D (data not shown) was higher than from ground applications. The higher control levels on aerially treated plots, 87 and $88 \%$ from $1.12 \mathrm{~kg} /$ ha of the amine and ester formulations, respectively, compared to 35 and $52 \%$, respectively, on plots treated with ground equipment, were attributed to use of the diesel oil:water emulsion as carrier for aerial applications. Sperry and Sultemeier (1965) postulated that oil:water emulsion carriers would improve bitterweed control compared to water carrier, especially under less than optimum conditions for spraying. Oil-based carriers and ester herbicides penetrate the cuticle more effectively

Table 4. Average percent reduction in the live bitterweed densities 48,113 and 489 days after application of various herbicides and herbicide combinations in early December 1976 at three locations in the Edwards Plateau of Texas.

\begin{tabular}{|c|c|c|c|c|}
\hline \multicolumn{2}{|l|}{ Treatment } & \multirow{2}{*}{\multicolumn{3}{|c|}{ Reduction $(\%)$ in density }} \\
\hline \multirow[b]{2}{*}{ Herbicide(s) } & \multirow{2}{*}{$\begin{array}{c}\text { Rate } \\
\text { (kg/ha) }\end{array}$} & & & \\
\hline & & 48 & 113 & $489^{2}$ \\
\hline None & - & $0 \mathrm{a}$ & $0 \mathrm{a}$ & $0 \mathrm{a}$ \\
\hline Carrier only ${ }^{3}$ & - & $0 \mathrm{a}$ & $0 \mathrm{a}$ & $6 \mathrm{ab}$ \\
\hline 2,4-D & 1.12 & $20 \mathrm{~b}-\mathrm{e}$ & $43 \mathrm{c}$ & $40 \mathrm{abc}$ \\
\hline 2,4-D + dicamba (3:1) & 1.12 & 18 bcd & $90 \mathrm{~d}$ & 62 abc \\
\hline $2,4,5-T+$ picloram $(1: 1)$ & 0.56 & $29 \mathrm{de}$ & $92 \mathrm{~d}$ & $60 \mathrm{abc}$ \\
\hline $2,4,5-\mathrm{T}+$ picloram $(1: 1)$ & 1.12 & $34 \mathrm{de}$ & $89 \mathrm{~d}$ & $57 \mathrm{abc}$ \\
\hline Picloram & 0.28 & $32 \mathrm{de}$ & $100 \mathrm{~d}$ & $61 \mathrm{abc}$ \\
\hline Picloram & 0.56 & $21 \mathrm{~b}-\mathrm{e}$ & $90 \mathrm{~d}$ & $60 \mathrm{abc}$ \\
\hline Picloram & 1.12 & $36 \mathrm{e}$ & $91 \mathrm{~d}$ & $89 \mathrm{c}$ \\
\hline Tebuthiuron & 0.56 & $4 a b$ & $23 \mathrm{~b}$ & $97 \mathrm{c}$ \\
\hline Tebuthiuron & 1.12 & $8 a b c$ & $35 \mathrm{bc}$ & $88 \mathrm{c}$ \\
\hline
\end{tabular}

IMeans within a column followed by the same letter are not significantly different at $P<0.05$.

${ }^{2}$ Results from near San Angelo only.

${ }^{3}$ Sprayed with 140 liters/ ha of the diesel oil:water (1:14) emulsion carrier containing no herbicide. than polar carriers or water-soluble herbicide formulations (amines) (Klingman and Ashton 1975). Therefore, when oil: water emulsion carriers were used in subsequent experiments, a set of plots were treated with the carrier only to allow isolating any carrier/herbicide interactions. In no case, however, did the oil:water emulsion applied without herbicide damage the bitterweed (Table 4). Moreover, subsequent applications of 2,4-D in the diesel oil:water emulsion did not result in the high initial levels of control observed following aerial applications near Mertzon.

In May, 140 days after herbicide application near Mertzon, percentage bitterweed control exceeded $90 \%$, regardless of 2,4-D rate or formulation applied with ground equipment (Table 3), even though only $10 \mathrm{~cm}$ of rainfall occurred. Also, there was no difference in bitterweed control whether the 2,4-D was applied with ground (water carrier) or aerial equipment (diesel oil:water emulsion) (data not shown). Bitterweed plants on the plots, seedlings that germinated after spraying, reflected the short residual life of 2,4-D in the soil. Seedling establishment was also evident at 182 days after spraying. By 310 days after spraying near Mertzon, only the $1.12 \mathrm{~kg} /$ ha rate of $2,4-\mathrm{D}$, whether applied with ground (Table 3 ) or aerial equipment (data not shown), reduced the bitterweed density.

There was no significant difference in bitterweed control between the amine and ester of 2,4-D near Mertzon. Also, there was no apparent advantage to combining the amine and ester formulations. A 1:1 combination of the formulations aerially applied at $1.12 \mathrm{~kg} /$ ha total herbicide resulted in bitterweed control levels equivalent to those from the same rate of either formulation applied alone (data not shown).

Data from winter herbicide applications with ground equipment near San Angelo, Barnhart, and Ozona were averaged for presentation. Since there was no difference between 2,4-D formulations relative to bitterweed control in the previous experiments, only the ester at $1.12 \mathrm{~kg} /$ ha was applied. On the average, 2,4-D ester reduced the bitterweed densities $20 \%$ after 48 days and $43 \%$ after 113 days (Table 4 ). These control levels were substantially lower than were achieved following application of the same rate of the ester during the winter of 1975 (Table 3). Environmental conditions during spraying were assumed responsible for this difference. Although soil water contents of the surface $8 \mathrm{~cm}$ the day of treatment, 32\% (San Angelo), 25\% (Barnhart), and $27 \%$ (Ozona), were higher than near Mertzon the previous year, air temperatures were considerably lower. At the time of 2,4-D application near Ozona, air temperature was only $5^{\circ} \mathrm{C}$ and surface soil temperature was $7^{\circ} \mathrm{C}$. Maximum air and surface soil temperature were $12^{\circ} \mathrm{C}$ the day of spraying near Barnhart, and $14^{\circ} \mathrm{C}$ and $11^{\circ} \mathrm{C}$ respectively, the day of spraying near San Angelo. Thus, the average maximum air temperature during 2,4-D applications in 1976 , about $10^{\circ} \mathrm{C}$, was $12^{\circ} \mathrm{C}$ lower than during 1975 applications. Surface soil temperatures averaged $6^{\circ} \mathrm{C}$ lower in 1976 than in 1975. Apparently, the lower temperatures in 1976 accounted for decreased short-term bitterweed control with 2,4-D compared to 1975. Control of bitterweed with 2,4-D ester at $1.12 \mathrm{~kg} /$ ha was about $40 \%$ at 310 days after spraying in 1975 and at 489 days after spraying in 1976.

At the time of herbicide application in May 1976 near Mertzon, the bitterweed plants were 3 to $10 \mathrm{~cm}$ tall and more than $85 \%$ of the population was in full flower. Maximum air 
temperature was $18^{\circ} \mathrm{C}$ the day of spraying. Rainfall 60 days prior to treatment totaled only $2.8 \mathrm{~cm}$, about $4 \mathrm{~cm}$ below normal. There were essentially no seedlings in the bitterweed stand and soil water content was only $10 \%$ in the upper $15 \mathrm{~cm}$. However, $17 \mathrm{~cm}$ of rainfall occurred within 30 days following spraying. Both 2,4-D formulations had reduced bitterweed density by over $80 \%$ at 30 days following treatment (data not shown). Since the remainder of the summer was dry, no live bitterweed plants occurred on the plots, regardless of treatment, in August. Rainfall was $15 \mathrm{~cm}$ below normal from July through October, and in November there was no difference in bitterweed densities between untreated plots and those treated with 2,4-D.

Data were averaged from two experiments installed in the spring of 1977 near Ft. McKavett and Sterling City. Shortterm bitterweed control from 2,4-D applications in the spring of 1977 (Table 5) was similar to that from treatments in the winter of 1976, but was lower than control after spraying in the spring of 1976. At the time of 2,4-D applications near Sterling City and Ft. McKavett, the bitterweed plants were 8 to $15 \mathrm{~cm}$ tall and about $75 \%$ of the populations was in full flower. Surface soil water contents averaged $22 \%$ near Sterling City and 34\% near Ft. McKavett. Air and surface soil temperatures were $26^{\circ} \mathrm{C}$ during spraying near Sterling City and $14^{\circ} \mathrm{C}$ and $16^{\circ} \mathrm{C}$, respectively, at Ft. McKavett. Although environmental conditions were more favorable for maximum herbicide activity during the spring of 1977, especially at Sterling City, than during the previous winter, 2,4-D activity was apparently reduced by the advanced phenological development of bitterweed. Reduction in bitterweed density was only $16 \%$ after 40 days (Table $5)$. These results substantiate the conclusion of Sperry and Sultemeier (1965) that bitterweed is less susceptible to 2,4-D after full flower development than when treated in earlier stages. The difference in control of bitterweed from applications of 2,4-D in the spring 1976, compared to 1977, exemplify the erratic response of bitterweed after flowering to 2,4-D. Also, bitterweed density reductions averaged $60 \%$ at 354 days after spraying in the spring 1977 (Table 5). The reason for this prolonged control is unclear, especially in view of the lack of residual control from applications of 2,4-D in the spring of 1976 and from all experiments established in the winter.

\section{Control with Residual Herbicides}

Bitterweed control 140 to 182 days after ground applica-

Table 5. Average percentage reduction in live bitterweed densities $\mathbf{4 0}$ and 354 days after ground application of various herbicides and herbicide combinations in late April 1977 on the Edwards Plateau.

\begin{tabular}{|c|c|c|c|}
\hline \multicolumn{2}{|c|}{ Treatment } & \multirow{2}{*}{\multicolumn{2}{|c|}{ Days after treatment }} \\
\hline \multirow[b]{2}{*}{ Herbicide(s) } & \multirow{2}{*}{$\begin{array}{c}\text { Rate } \\
(\mathrm{kg} / \mathrm{ha})\end{array}$} & & \\
\hline & & $40^{2}$ & $354^{3}$ \\
\hline None & - & $0 \mathbf{a}$ & $0 \mathbf{a}$ \\
\hline 2,4-D & 1.12 & $16 \mathrm{a}$ & $60 \mathrm{~b}$ \\
\hline 2,4-D + dicamba $(3: 1)$ & 1.12 & $74 \mathrm{~b}$ & $73 \mathrm{~b}$ \\
\hline $2,4,5-\mathrm{T}+$ picloram $(1: 1)$ & 0.56 & $91 \mathrm{~b}$ & $85 \mathrm{~b}$ \\
\hline $2,45-\mathrm{T}+$ picloram $(1: 1)$ & 1.12 & $71 \mathrm{~b}$ & $89 \mathrm{~b}$ \\
\hline Picloram & 0.28 & $77 \mathrm{~b}$ & $82 \mathrm{~b}$ \\
\hline Picloram & 0.56 & $77 \mathrm{~b}$ & $89 \mathrm{~b}$ \\
\hline Picloram & 1.12 & $100 \mathrm{~b}$ & $100 \mathrm{~b}$ \\
\hline
\end{tabular}

'Means within a column followed by the same letter are not significantly different at $P<0.05$ according to Duncan's new multiple range test.

${ }^{2}$ Average of two experiments.

${ }^{3}$ Means from near Ft. McKavett only. tion of herbicides in December 1975 with 2,4-D + dicamba (3:1) or picloram was no different from that with 2,4-D at $1.12 \mathrm{~kg} /$ ha (Table 3). These results were substantiated on plots aerially sprayed on the same date near Mertzon (data not shown). Picloram $+2,4,5-\mathrm{T}(1: 1)$ at $0.56 \mathrm{~kg} /$ ha also provided no advantage over 2,4-D following aerial application (data not shown). However, 310 days after aerial application of picloram at 0.56 and $1.12 \mathrm{~kg} / \mathrm{ha}$, bitterweed control was 89 and $92 \%$, respectively. There was essentially no residual control at 310 days after application of 0.14 $\mathrm{kg} / \mathrm{ha}$ of picloram with ground equipment near Mertzon, only $25 \%$ reduction in bitterweed densities where $0.28 \mathrm{~kg} / \mathrm{ha}$ was applied, but a $72 \%$ reduction where $0.56 \mathrm{~kg} / \mathrm{ha}$ was applied (Table 3). These responses might be expected based on the residual life of picloram in semiarid rangeland soils. Picloram residues following application of $0.28 \mathrm{~kg} /$ ha were restricted to the surface $30 \mathrm{~cm}$ for about 60 days (Scifres et al. 1971), and residues may last for a year or longer in rangeland soils after application of $1.12 \mathrm{~kg} /$ ha or more of the herbicide, especially if treatments are made during the cool season (Bovey and Scifres 1971).

Residual bitterweed control 310 days after ground application of 2,4-D + dicamba at $1.12 \mathrm{~kg} / \mathrm{ha}$ in December 1975 was similar to that from both 2,4-D formulations at the same rate (Table 3 ). These data indicate no advantage of picloram, 2,4,5-T + picloram, or 2,4-D + dicamba, at the rates studied, over $2,4-\mathrm{D}$ at $1.12 \mathrm{~kg} /$ ha for short-term control of bitterweed if applied when soil moisture is adequate for plant growth, the ambient temperature is above $21^{\circ} \mathrm{C}$, and when bitterweeds are rapidly developing vegetatively. Dicamba persists in the soil for less than 4 weeks after application of $0.28 \mathrm{~kg} / \mathrm{ha}$ or less in the spring (Scifres and Allen 1973). Although residues might persist somewhat longer following spraying in the winter, rapid detoxification the following spring apparently reduced residual effects for bitterweed control in these studies.

Bitterweed control 48 days after ground application of herbicides in December 1976 (Table 4) was similar to initial control from treatments in December 1975 (Table 3). Bitterweed control with tebuthiuron at 0.56 to $1.12 \mathrm{~kg} /$ ha was similar to that from $2,4-\mathrm{D}$ or from the combination of dicamba and 2,4-D at $1.12 \mathrm{~kg} /$ ha (Table 4). However, picloram and $2,4,5-\mathrm{T}+$ picloram at $1.12 \mathrm{~kg} /$ ha controlled significantly more bitterweed than tebuthiuron at the same rate (Table 4). Good-to-excellent control of bitterweed resulted from 2,4-D + dicamba, 2,4,5-T + picloram, and picloram after 113 days. However, bitterweed control from 2,4-D or tebuthiuron was unsatisfactory (Table 4). Apparently, herbicides containing picloram or dicamba compensated for the cold temperatures $\left(5\right.$ to $\left.14^{\circ} \mathrm{C}\right)$ at time of application, either through increased foliar absorption or by a combination of foliar and root absorption, compared to 2,4-D or tebuthiuron. Similar results occurred after aerial application of herbicides in December 1976 near Barnhart (data not shown).

Although most herbicide treatments did not significantly reduce bitterweed density 489 days after spraying near San Angelo (Table 4), there was an obvious trend toward: (1) lower residual control with 2,4-D compared to all other herbicides and (2) similar residual control with 2,4-D + dicamba, $2,4,5-\mathrm{T}+$ picloram, and picloram at 0.28 or 0.56 $\mathrm{kg} / \mathrm{ha}$. Picloram at $1.12 \mathrm{~kg} /$ ha or either rate of tebuthiuron significantly reduced the bitterweed density compared to untreated rangeland after 489 days. Lack of sufficient pre- 
cipitation for establishment of bitterweed prevented evaluation of long-term effects of herbicides in other experiments initiated in winter 1976. However, these data substantiated the finding from plots aerially treated in December 1975; picloram at $1.12 \mathrm{~kg} /$ ha provided good-to-excellent residual control of bitterweed.

In November 1976, after application of herbicides in May near Mertzon, only picloram had reduced the reinvasion of bitterweed. Bitterweed densities were 70 to $93 \%$ lower where 0.56 and $1.12 \mathrm{~kg} /$ ha of picloram were applied, respectively, than on untreated plots (data not shown). At 40 days after spraying bitterweed in late April 1977, the 2,4-D + dicamba, 2,4,5-T + picloram, and picloram treatments resulted in significantly better control than 2,4-D (Table 5). Herbicides containing dicamba or picloram overcame the influence of phenological stage (75\% of the plants were in full flower), which apparently negated herbicidal effects of 2,4-D. After 354 days, all herbicides provided control of bitterweed at the Ft. McKavett location (Table 5). The effects of residual herbicide activity and competition from associated species were confounded in this study. Although there was no significant differences in control of bitterweed among the herbicides applied in the spring (Table 5), there were several obvious trends including: (1) residual control from 2,4-D was less than from herbicides containing dicamba or picloram; (2) residual control from 2,4-D + dicamba was intermediate between that from 2,4-D and that from herbicides containing picloram; and (3) residual control increased as the amount of picloram applied increased from 0.28 to 1.12 $\mathrm{kg} / \mathrm{ha}$. In this experiment, excellent control of bitterweed was achieved with all herbicides containing picloram (minimum of $0.28 \mathrm{~kg} / \mathrm{ha}$ ). The addition of 2,4,5-T to picloram had no additive effect, relative to bitterweed control, compared to the same rate of picloram alone (Tables 4 and 5).

These results support those from previous experiments, that picloram at $1.12 \mathrm{~kg} /$ ha provides long-term residual control of bitterweed. The data also suggest that lower rates of picloram may be more effective for long-term control when applied in the spring than in winter. Also, based on a single experiment, tebuthiuron appears to be as effective for long-term control of bitterweed as equivalent rates of picloram.

\section{Conclusions}

Herbicidal control of bitterweed with 2,4-D was severely reduced at air temperatures below $14^{\circ} \mathrm{C}$ and surface soil temperatures below $12^{\circ} \mathrm{C}$, even when soil-water contents exceeded $25 \%$. However, excellent short-term control resulted with 2,4-D applied at $22^{\circ} \mathrm{C}$ air temperature, $16^{\circ} \mathrm{C}$ surface soil temperature, and when surface soil-water content averaged $20 \%$. There was no difference between amine and ester formulations of 2,4-D for bitterweed control when applied with air and surface soil temperature of $22^{\circ} \mathrm{C}$ and $16^{\circ} \mathrm{C}$, respectively. Also, there was no advantage to mixing the amine and ester formulations of 2,4-D.
Winter applications of 2,4-D + dicamba, 2,4,5-T + picloram, or picloram provided no advantage for short-term control of bitterweed over 2,4-D applied when air temperature was $22^{\circ} \mathrm{C}$ and surface soil temperature was $16^{\circ} \mathrm{C}$. However, these herbicide treatments resulted in excellent control of bitterweed at 113 days after winter spraying when air surface temperatures were below optimum for 2,4-D.

The ester of 2,4-D did not consistently control bitterweed in the spring when $75 \%$ of the plants were in full flower, whereas good-to-excellent control was achieved with 2,4-D + dicamba at $1.12 \mathrm{~kg} / \mathrm{ha}, 2,4,5-\mathrm{T}+$ picloram at 0.56 to 1.12 $\mathrm{kg} / \mathrm{ha}$, and picloram at 0.28 to $1.12 \mathrm{~kg} / \mathrm{ha}$. There was no advantage to mixing $2,4,5-\mathrm{T}$ with picloram.

All herbicide treatments resulted in some bitterweed control for a year or more after spraying in either spring or winter. Picloram and tebuthiuron at 0.56 to $1.12 \mathrm{~kg} / \mathrm{ha}$ were the most effective treatments for long-term control. Tebuthiuron, however, was no more effective than 2,4-D for short-term control of bitterweed after winter applications.

Based on these data, some factors which reduce the effectiveness of 2,4-D for control of bitterweed, including low temperatures, advanced phenological stage of the weed, and lower residual activity can be overcome by the addition of dicamba to 2,4-D or by the use of picloram. The range of soil water contents in these experiments was not adequate to allow comparison of these herbicides with 2,4-D for control of bitterweed under severe moisture stress.

\section{Literature Cited}

Ashton, F.M., and A.S. Crafts. 1973. Mode of Action of Herbicides. John Wiley and Sons, New York. 504 p.

Boughton, I.B., and W.T. Hardy. 1937. Toxicity of bitterweed (Actinea odorata) for sheep. Texas Agr. Exp. Sta. B-552. 15 p.

Bovey, R.W., and C.J. Scifres. 1971. Residual characteristics of picloram in grassland ecosystems. Texas Agr. Exp. Sta. Bull. 1111. 24 p.

Bunting, S.C., and H.A. Wright. 1974. Controlling bitterweed with fall and winter applications of 2,4-D amine. J. Range Manage. 27: 381-382.

Clawson, A.B. 1931. A preliminary report on the poisonous effects of bitter rubber weed (Actinea odorata) on sheep. J. Agr. Res. 43: 693-701.

Dollahite, J.W., L.D. Rowe, H.L. Kim, and B.J. Camp. 1973. Control of bitterweed (Hymenoxys odorata) poisoning in sheep. Texas Agr. Exp. Sta. PR-3149. 8 p.

Kim, H.L., L.D. Rowe, and B.J. Camp. 1975. Hymenoxon, a poisonous sesquiterpene lactone from Hymenoxys odorata (bitterweed). Res. Comm. Chem. Path. Phar. 11: 647.

Klingman, G.C., and F.M. Ashton. 1975. Weed Science. Principles and Practices. John Wiley and Sons, New York. 431 p.

Leopold, C.A., and P.E. Kriedemann. 1975. Plant Growth and Development (2nd Ed.). McGraw-Hill Book Co., New York. 545 p.

Scifres, C.J., R.R. Hahn. J. Diaz-Colon, and M.G. Merkle. 1971. Picloram persistence in semiarid rangeland soils and water. Weed Sci. 19: 381-384.

Scifres, C.J., and T.J. Allen. 1973. Dissipation of dicamba from grassland soils of Texas. Weed Sci. 21: 393-396.

Sperry, O.E. 1949. The control of bitterweed (Actinea odorata) on Texas ranges. J. Range Manage. 2: 122-127.

Sperry, O.E., and G.W. Sultemeier. 1965. Bitterweed. . .Its control in relation to soil moisture. Sheep and Goat Raiser. 45: 14-17.

Sultemeier, G.W. 1961. Responses of bitterweed (Hymenoxys odorata) to 2,4-D in relation to soil moisture. MS Thesis. Texas A\&M Univ., College Station, Texas. $68 \mathrm{p}$. 